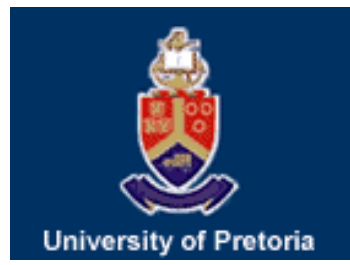

University of Pretoria Department of Economics Working Paper Series

Determinants of South Africa's Exports of Leather Products André C. Jordaan University of Pretoria Joel Hinaunye Eita University of Pretoria Working Paper: 2007-21 October 2007

Department of Economics

University of Pretoria

0002, Pretoria

South Africa

Tel: +27 124202413

Fax: +27 123625207

http://www.up.ac.za/up/web/en/academic/economics/index.html 


\title{
DETERMINANTS OF SOUTH AFRICA'S EXPORTS OF LEATHER PRODUCTS
}

\author{
Andre C. Jordaan \\ Investment and Trade Policy Centre \\ Department of Economics \\ University of Pretoria \\ Email: andre.jordaan@up.ac.za \\ Joel Hinaunye Eita \\ Investment and Trade Policy Centre \\ Department of Economics \\ University of Pretoria \\ Email: hinaeita@yahoo.co.uk
}

\begin{abstract}
This paper analysed the determinants of South African exports of raw hides and skins (other than fur skins) and leather (H41) using annual data covering the period 1997 to 2004 for 32 main trading partners. The results show that importer's GDP, South Africa’s GDP, importer's population, South Africa's population, infrastructure of South Africa and importing country and some regional trade agreements are the main determinants of raw hides and skins (other than fur skins) and leather exports. The paper then investigated if there is unexploited trade potential. The investigation revealed that among others, South Korea, United Kingdom, USA, Zambia and Zimbabwe have unexploited export potential. It is important to focus efforts on the unexploited trade potential to accelerate growth and alleviate poverty in South Africa.
\end{abstract}

JEL: C01, C23, F10, F17, F47

Keywords: gravity model, fixed effects, export potential 


\section{Introduction}

The issue of how a country can achieve high economic growth is one of the fundamental economic questions. An export-led growth hypothesis which states that exports are one of the keys to achieving high economic growth provides a possible answer to this fundamental question. Export of goods and services is an important source of foreign exchange reserves and can reduce balance of payments problems, and creates employment opportunities. According to Abou-Sait (2005) an export-led growth strategy aims to provide producers incentives to export their goods through various policies. The strategy also aims at increasing the capability of producing goods that can compete in the world market using advanced technology and make provision for foreign exchange needed to import capital goods. Exports can help the country to integrate into the world economy and help to reduce the impact of external shocks on the domestic economy. They allow domestic production to achieve a high level of economies of scale. Studies such as Tsen (2006) stated that the experiences of East Asian economies provide good examples of the importance of the export sector to economic growth and development. This indicates the role of exports as an engine for economic growth.

The importance of exports in economic growth led to many countries such as South Africa to adopt an export-led growth strategy, known as the Growth Employment and Redistribution (GEAR) strategy in 1996 (Naude, Oostendorp and Serumaga-Zake, 2005:

1). Various measures were introduced under this strategy in 1996 in order to promote 
exports. In 2005, under the Accelerated Shared Growth Initiatives - South Africa (ASGISA) the South African government indicated that it wants to accelerate growth and halve poverty by 2014 (The Presidency Republic of South, 2005). Growth acceleration and halving of poverty can be achieved by promoting exports.

Although the leather sector accounted for 4.4 percent of South African exports during the period 1997 to 2004, its development and promotion may contribute towards achieving the objective of halving poverty and reducing unemployment by means of high levels of economic participation and income generation. Given its expected significance and role in the South African export sector, it is important to determine its trade potential between South Africa and its trading partners. A gravity model is a useful tool in determining the trade or export potential of a country. The model has its foundations in physical sciences and had proven to be very important in the analysis of bilateral trade flows. Tinbergen (1962) and Poyhonen (1963) pioneered the idea of explaining trade flows in analogy to Newton's law of gravity by the attraction of two countries' masses, weakened by distance between them and enforced by preferential trade agreements they belong to. The masses of countries are measured by GDP or population and distance between countries measures transport costs. As in physical sciences, the bigger and the closer the units are to each other, the stronger the attraction. The comparison with gravity derives from GDP being a proxy for economic mass and distance as a proxy for resistance. 
The gravity model is used to analyse the relationship between volume and direction of international trade and the formation of regional trade agreements where members are in different stages of development. The basic gravity model is augmented with a number of variables to test whether they are relevant in explaining trade between countries (Martinnez-Zarzoso and Nowak-Lehmann, 2003). These variables include GDP, distance, infrastructure, differences in per capita income and exchange rates.

The objective of this paper is to analyse the factors determining exports of raw hides and skins (other than furskins) and leather (H41) using a gravity model approach. The paper then investigates whether there is any unexploited trade potential between South Africa and its trading partners within this sector. The rest of the paper is organised as follows. Section 2 discusses the gravity model. Section 3 discusses the estimation methodology, while Section 4 presents univariate characteristics of the data. The estimation results for the gravity model are presented in Section 5 while Section 6 discusses potential trade. The conclusion is provided in section 7 .

\section{The Gravity Model}

The gravity model was the first applied to international trade in the early 1960s by Tinbergen (1962) and Poyhonen (1963). The model has been used in the latter half of the nineteenth century to explain migration and other social flows in terms of gravitational forces of human interaction. As in physical science, the bigger and the closer the units are to each other, the stronger the attraction. The comparison with gravity results from GDP 
being a proxy for economic mass and distance as a proxy for resistance. Although the gravity model performed very well in analysing trade flows in the 1960s, its strong theoretical foundations were not produced until the end of the 1970s. This led to many studies to modify the original Newtonian gravity equation. Anderson (1979) and Bergstrand $(1985,1989)$ made it clear that the gravity model is a good representation irrespective of the structure of product markets. Bergstrand $(1985,1989)$ included the population size, while Oguledo and Macphee (1994) included a measure of the price variable.

Oguledo and Macphee (1994) derived the gravity equation from the linear expenditure system, in an attempt to answer criticisms that the theoretical foundation of the gravity model was weak. Their analysis assumed a weakly separable utility function from which a linear expenditure function could be derived.

The basic gravity equation explains the size of exports from country $i$ to country $j$ by three factors. The first indicates the total potential supply of the exporting country (i), and the second one indicates the potential demand of the importing country $(j)$, and the third includes factors which represents the resistance to trade flow between countries. In its basic form, exports from country $i$ to country $j$ are determined by their economic sizes (GDP), population, geographical distances and a set of dummies which incorporate some kind of institutional characteristics common to specific flows. The gravity model is generally specified as (Martinez-Zarzoso and Nowak-Lehmann, 2003: 296; Jakab, Kovacs and Oszlay, 2001: 280; Breuss and Egger, 1999: 83): 
$\ln X_{i j}=\beta_{0}+\beta_{1} \ln Y_{i}+\beta_{2} \ln Y_{j}+\beta_{3} \ln P O P_{i}+\beta_{4} \ln P O P_{j}+\beta_{5} \ln D I S_{i j}+\beta_{6} \ln A_{i j}+u_{i j}$

where $X_{i j}$ is exports of goods from country $i$ to country $j, Y_{i}$ and $Y_{j}$ are the GDP of the exporter and importer, $P O P_{i}$ and $P O P_{j}$ are the populations of the exporter and importer, $D I S T_{i j}$ is the distance in kilometres between the two countries, $A_{i j}$ represents any factor that influence trade between the countries, and $u_{i j}$ is the error term.

A high level of GDP indicates a high level of production in the exporting country and can be interpreted as a proxy for the range of product varieties available, which increases the availability of exports. It represents potential supply of exports. The importer's GDP represents potential demand for imports. A high level of GDP or income in the importing country suggests high imports. The coefficients $\beta_{1}$ and $\beta_{2}$ are expected to have positive signs. The population variables can influence export in two ways. A large population indicates a large domestic market and higher degree of self-sufficiency and less need to trade (Nilsson, 2000). Large populations also encourage division of labour and this means that there will be economies of scale in production, and opportunities to trade with a variety of goods. For the exporting country, a large population can increase or decrease trade depending on whether the country exports more when it is large or whether the large country export less than the smaller one. For the importing country a large population can also increase or decrease trade for the same reasons. Thus, the effects of population for both the exporting and importing countries cannot be assigned a priori. 
That means $\beta_{3}$ and $\beta_{4}$ are expected to have ambiguous signs (Oguledo and MacPhee, 1994). The coefficient of distance, $\beta_{5}$ is expected to be negative because it is a measure of transport costs.

Several studies (such as Longo and Sekkat, 2004; Bougheas, Demetriades and Morgenroth, 1999) extended the gravity equation to examine the impact of infrastructure on exports. Mátyás (1997) and Tri Do (2006) also extended the gravity model by including the real exchange rate. Equation (1) is then re-specified as:

$$
\begin{aligned}
\ln X_{i j}= & \beta_{0}+\beta_{1} \ln Y_{i}+\beta_{2} \ln Y_{j}+\beta_{3} \ln P O P_{i}+\beta_{4} \ln P O P_{j}+\beta_{5} \ln D I S_{i j}+ \\
& \beta_{6} \ln I N F R A_{i}+\beta_{7} \ln I N F R A_{j}+\beta_{8} \ln R E R_{i j}+\beta_{9} \ln A_{i j}+u_{i j}
\end{aligned}
$$

where, INFRA and INFRA $A_{j}$ are measures of the infrastructure in countries $i$ and $j$, and $R E R_{i j}$ is the real exchange rate between countries $i$ and $j$. Good infrastructure in both the exporting and importing countries are associated with an increase in exports. A depreciation of the real exchange rate causes an increase in exports. The coefficients $\beta_{6}$ and $\beta_{7}$ are expected to be positive, while $\beta_{8}$ is negative because an increase in real exchange rate in this study is defined as appreciation.

A number of studies (Carrère, 2006; Silva and Tenreyro, 2006; Jakab, Kovács and Oszlay, 2001) used the gravity model as a useful tool in assessing the trade creating and trade diverting effects that are associated with trade agreements. These studies also used language as an additional variable to explain trade flows between countries. This paper 
introduces dummy variables (included in $A_{i j}$ ) to represent various regional trade agreements and English language. The dummy variables take the value one for membership of trade agreements or where English is the official language, and zero otherwise. The introduction of dummy variables modifies Equation (2) as:

$$
\begin{aligned}
\ln X_{i j}= & \beta_{0}+\beta_{1} \ln Y_{i}+\beta_{2} \ln Y_{j}+\beta_{3} \ln P O P_{i}+\beta_{4} \ln P O P_{j}+\beta_{5} \ln D I S_{i j}+ \\
& \beta_{6} \ln I N F R A_{i}+\beta_{7} \ln I N F R A_{j}+\beta_{8} \ln R E R_{i j}+\beta_{9} A S I A+\beta_{10} E U+ \\
& \beta_{11} N A F T A+\beta_{12} L A N G+u_{i j}
\end{aligned}
$$

where ASIA is for countries which are part of Asia, EU is the dummy variable for membership of the European Union, LANG is for countries with a common language (in

this case English), NAFTA is the dummy variable for membership of North America Free Trade Agreement. A common language between countries is associated with an increase in trade between countries. Since membership of trade agreements can results in trade creation or trade diversion, the coefficients can be positive or negative. Common language may also be expected to promote trade, and therefore its coefficient is expected to have positive sign.

\section{Estimation Methodology}

Different models can be estimated in panel data regressions, which include pooled, fixed and random effects. Since the regressions include individual effects, it is important to decide whether random or fixed effects is the appropriate model. When estimating the trade flows between a randomly drawn sample of trading partners from a large population 
a random effect model is more appropriate, while a fixed effects model is more appropriate when estimating the flows of trade between an ex ante predetermined selection of countries (Egger, 2000: 26; Martinez-Zarzoso and Nowak-Lehmann, 2003: 299). This paper analyses the trade between South Africa and 32 main trading partners in the leather sector, and therefore the fixed effects will be a better model than the random effects model. The 32 main trading partners were selected based on the trade statistics of raw hides and skins (other than fur skins) and leather (H41) for the period 1997 to 2004. The Hausman test statistic is employed to check further whether the fixed effects model is better than the random effects model. If the null hypothesis of no correlation between the individual or fixed effects and regressors is rejected, then the fixed effects model is better than the random effects model.

The fixed effects model has a problem as it does not estimate directly variables that do not change over time because inherent transformation wipes out such variables. This problem can be solved in a second step by estimating another regression with the individual effects as the dependent variable and distance and dummy variables as explanatory variables. This is elucidated as:

$$
I E_{i j}=\gamma_{0}+\gamma_{1} D I S_{i j}+\gamma_{2} L A N G+\gamma_{3} A S I A+\gamma_{4} E U+\gamma_{5} N A F T A+\mu_{i j}
$$

where $I E_{i j}$ is individual effects (originating from the fixed effects model), and other variables are as defined before. 


\section{Univariate Characteristics of Variables}

The paper analysed the univariate characteristics of the variables which entails panel unit root tests prior to the estimation of Equation (3). This is the first step in determining a potentially cointegrated relationship between the variables. If all variables are stationary, then the traditional estimation method can be used to estimate the relationship between variables. The detailed data source and description are provided in the Appendix. If the data are nonstationary, a cointegration test should be performed. There are three main different types of panel unit root tests. The first test is that of Levin, Lin and Chu (2002) and the second is Hadri (2000). These tests assume that the autoregressive parameters are common across cross sections. Levin, Lin and Chu (LLC) uses the null hypothesis of a unit root while Hadri uses the null of no unit root. The third panel unit root test allows the autoregressive parameters to vary across cross sections as well as for individual unit root processes. The test was developed by Im, Pesaran and Shin (2003) and is referred to as IPS. It combines individual countries' unit root tests in order to come up with the result which is specific to the panel. According to Yigit and Straus (2003: 309), IPS has more power than the single equation Augmented Dickey Fuller (ADF) by averaging $\mathrm{N}$ independent ADF regressions. The specifications of the ADF tests can include an intercept but no trend or can include an intercept and a time trend. Under the IPS, the null hypothesis is that all series contain a unit root and the alternative hypothesis is that at least one series in the panel contain a unit root. IPS is a one-tailed or lower-tailed test and 
is based on $\mathrm{N}(0,1)$ distribution. This study applies the IPS and LLC tests and the results are presented in Table 1.

Table 1. Panel unit root test

\begin{tabular}{lll}
\hline Variable & LLC & IPS \\
\hline Export & $-6.235(0.000)^{* * *}$ & $-3.030(0.001)^{* * *}$ \\
Importer's GDP & $-17.517(0.000)^{* * *}$ & $-0.664(0.253)$ \\
South Africa's GDP & $-1.744(0.041)^{* *}$ & $-1.076(0.141)$ \\
Importer's Infrastructure & $-16.848(0.000)^{* * *}$ & $-1.628(0.052)^{*}$ \\
South Africa's Infrastructure & $-32.063(0.000)^{* * *}$ & $-7.795(0.000)^{* * *}$ \\
Importer's population & $-6.405(0.000)^{* * *}$ & $-0.151(0.440)$ \\
South Africa's population & $-59.972(0.000)^{* * *}$ & $-7.364(0.000)^{* * *}$ \\
Real exchange rate & $-4.569(0.000)^{*}$ & $-1.323(0.093)^{*}$ \\
\hline
\end{tabular}

Note: $* / * * / * * *$ Denote rejection of the null hypothesis at 10\%/5\%/1\% significance level

Probabilities are in parentheses.

The results of unit root test in Table 1 indicate that the LLC test shows that all variables are stationary. The IPS statistic elucidate that export, importer's infrastructure, South Africa's infrastructure, South Africa's population and real exchange rate are stationary, but importer's GDP, South Africa’s GDP and importer's population are non stationary. This paper uses at least one test to conclude that the variables are stationary. Since the variables are stationary according to the LLC test, it means that there is no need to test for cointegration, and Equation (3) can be estimated using the traditional estimation method. 


\section{Estimation Results}

The estimation results for both the pooled, fixed and random effects model are presented in Table 2. The pooled model has some shortcomings because it does not allow for heterogeneity of cross-sections, and cross-section specific effects are not estimated. It assumes that all cross-sections are homogenous. The pooled model is a restricted one and assumes a single intercept and same parameters over time and across countries. The results for the pooled model are in Column 2.

The results for the fixed effects model are in Column 3 while those of random effects model are presented in the last Column. Fixed effects model introduces heterogeneity and estimates country specific effects. The unrestricted models (fixed or random) allow the intercept and other parameters to differ across countries. The F-test was employed to test for poolability of the data. The result of the test rejects the null hypothesis of equality of the individual effects. This implies that a model with individual effects is more appropriate than the pooled model.

The random effects model also acknowledges heterogeneity of countries, but differs from the fixed effects model because it assumes that the effects are generated by a specific distribution. Although this model acknowledges differences in countries, it does

not model each effect separately. This prevents the loss of degrees of freedom which occurs under fixed effects. The LM test is applied to test the null hypothesis of no 
countries' heterogeneity against the alternative of random effects. The test rejects the null hypothesis of no countries' effects in favour of random effects specification.

The Hausman test specification is applied to test the null hypothesis that the regressors and individual effects are not correlated and to distinguish between fixed and random effects. Failure to reject the null hypothesis means that the random effects model is better than the fixed effects model. However, if the null hypothesis is rejected, the fixed effects model will be more appropriate than the random effects model. The result of the Hausman test shows that the null hypothesis is rejected, and this means that country specific effects are correlated with regressors. It implies that the fixed effects model is preferred. The interpretation of coefficients will focus on the fixed effects, because it is the preferred model. 
Table 2. Estimation results

Dependent variable: Export

\begin{tabular}{|c|c|c|c|}
\hline Variables & Pooled model & Fixed effects model & Random effects model \\
\hline Constant & $62.025(0.356)$ & $22.506(0.212)$ & $79.494(0.766)$ \\
\hline Importer’s GDP & $2.0411(7.526)^{* * *}$ & $1.154(2.262)^{* *}$ & $1.171(3.576)^{* * *}$ \\
\hline South Africa’s GDP & $2.062(1.017)$ & $2.429(2.013)^{* *}$ & $2.347(1.946)^{*}$ \\
\hline Importer's population & $-0.304(-2.409)^{* * *}$ & $5.320(1.872)^{*}$ & $-0.329(-1.100)$ \\
\hline South Africa's population & $-9.654(-0.709)$ & $-14.114(-1.718)^{*}$ & $-10.946(-1.353)$ \\
\hline Importer's infrastructure & $-0.762(-2.759)^{* * *}$ & $0.529(1.855)^{*}$ & $0.337(1.377)$ \\
\hline Africa's & $4.251(1.125)$ & $4.901(2.177)^{* *}$ & $4.941(2.197)^{* *}$ \\
\hline \multicolumn{4}{|l|}{ infrastructure } \\
\hline Real exchange rate & $-2.171-(-0.741$ & $-1.977(-1.131)$ & $-1.913(-1.097)$ \\
\hline Distance & $-1.086(-3.324)^{* * *}$ & & $-1.224(-1.593)$ \\
\hline English language dummy & $-0.960(-2.971)^{* *}$ & & $-1.160(-1.432)$ \\
\hline Asia dummy & $0.490(0.977)$ & & $0.751(0.597)$ \\
\hline EU dummy & $-1.034(-2.149)^{* *}$ & & $-1.017(-0.847)$ \\
\hline NAFTA & $-1.034(-1.528)$ & & $-1.266(-0.743)$ \\
\hline Adjusted R-squared & 0.395 & 0.786 & 0.681 \\
\hline F-test & & $15.215^{* * *}$ & \\
\hline LM test & & & $310.284 * * *$ \\
\hline Hausman test & & $14.076^{* *}$ & \\
\hline
\end{tabular}

Notes: $* / * * / * * * /$ significant at $10 \% / 5 \% / 1 \%$ level.

The t-statistics are in parentheses.

The results of the fixed effects model show that an increase in importer's GDP, South Africa's GDP, and population of the importing country causes the export of leather 
products to increase. South Africa's population is associated with a decrease in leather export and this means that as the population grows, the domestic market expands and there will be a reduction in export of leather products. An improvement in the infrastructure of the importing country and that of South Africa causes export of leather products to increase. An appreciation of the real exchange rate results in reduction of leather exports, but the coefficient is not statistically significant. All other coefficients are statistically significant.

The country specific effects are presented in Table A1 in the Appendix. The country specific effects show the effect of factors that are unique to each trading partner but not included the estimation of the model. They indicate that export of leather products between South Africa and its trading partners differs from country to country and each trading partner has unique features. It is shown in Table A1 that there are unique features in some trading partners that promote South Africa's export of leather products to Australia, Austria, Belgium, Czechoslovakia, Greece, Hong Kong, Mozambique, Netherlands, Portugal, Switzerland, United Arab Emirates, Uruguay, Zambia and Zimbabwe (countries shaded). The Table also show that there are unobservable country features that discourage trade to Brazil, Canada, China, France, Germany, India, Indonesia, Italy, Japan, South Korea, Mexico, Pakistan, Spain, Thailand, Turkey, United Kingdom and the United States of America (countries not shaded). This requires that trade policy analyst and policy makers should do an analysis of factors that discourage South Africa's export of leather products to countries with negative effects. This analysis will help to identify constraints to export of leather products to these countries. 
The second stage regression results are presented in Table 3. This regression includes some factors which potentially explain the fixed effects in Table A1. The results show that as expected, distance has a negative and significant effect on the export of leather products. Membership of the EU, ASIA, NAFTA, is associated with a decrease in export of leather products. This means that regional trade agreements causes trade diversion from South African leather products. South Africa exports less leather products to countries where English is the official language, and this is not consistent with theoretical expectation.

Table 3. Second stage regression: Dependent variable is fixed effects

\begin{tabular}{ll}
\hline Independent Variable & Coefficient (t-statistics) \\
\hline Constant & $32.121(9.620)^{* * *}$ \\
Distance & $-2.635(-6.409)^{* * *}$ \\
European Union Dummy & $-6.197(-7.147)^{* * *}$ \\
Asia dummy & $-9.696(-11.103)^{* * *}$ \\
NAFTA & $-11.954(-11.886)^{* * *}$ \\
English language dummy & $-5.567(-10.230)^{* * *}$ \\
\hline Adjusted R-squared & 0.834 \\
\hline
\end{tabular}

Note: */**/***/ significant at $10 \% / 5 \% / 1 \%$ level

\section{Export Potential}

The fixed effects of Equation (3) is simulated in order to determine the within export potential of leather products. The estimated export is then compared to actual export in 
order check if there is export potential which is not exploited. The results are presented in Figure 1. Figure 1 shows that among others, South Korea, the United Kingdom, United States of America, Zambia and Zimbabwe have unexploited export potential at least from 2002 to 2004. The potential exports for these countries exceed the actual exports. This suggests that it is important to promote export of leather products to these countries in order to exhaust the unexploited trade potential. An analysis of factors that discourage export potential of leather products is very important.

Figure 1. Export potential

\section{South Korea}

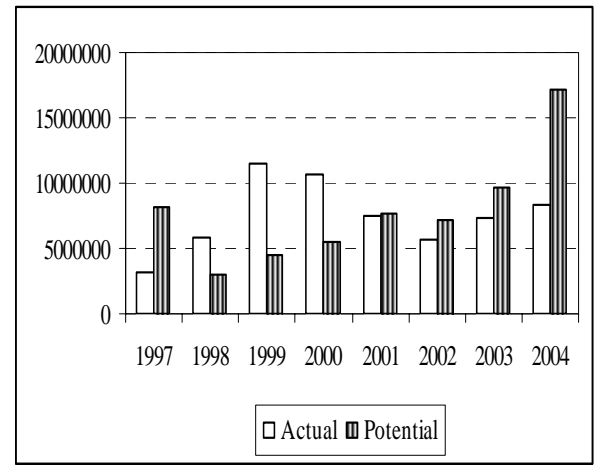

\section{United States of America}

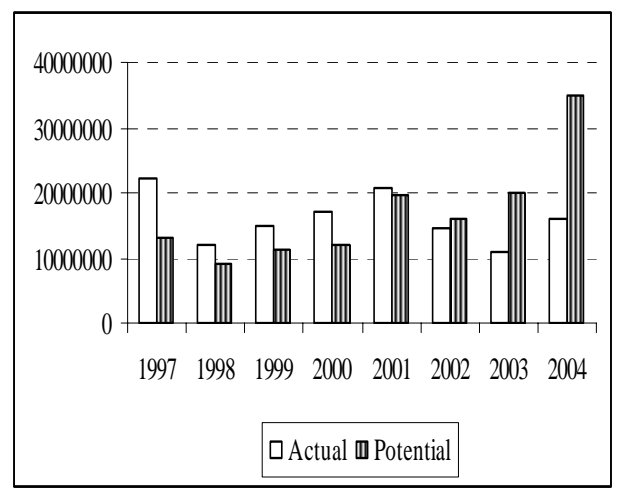

United Kingdom

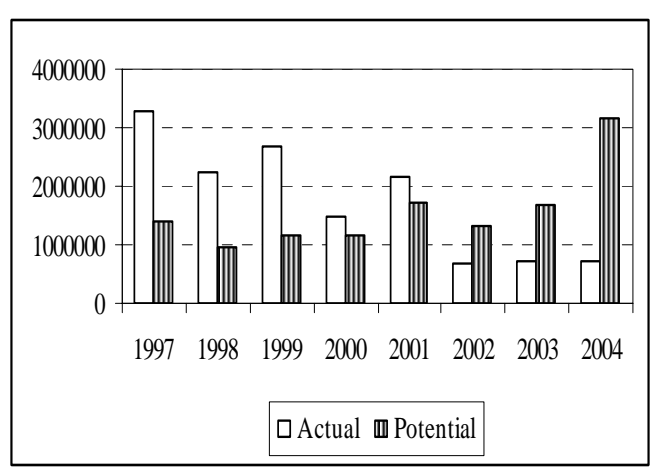

Zambia

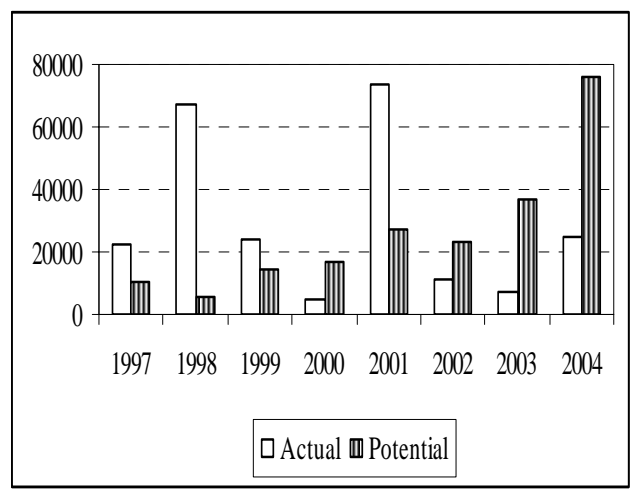




\section{Zimbabwe}

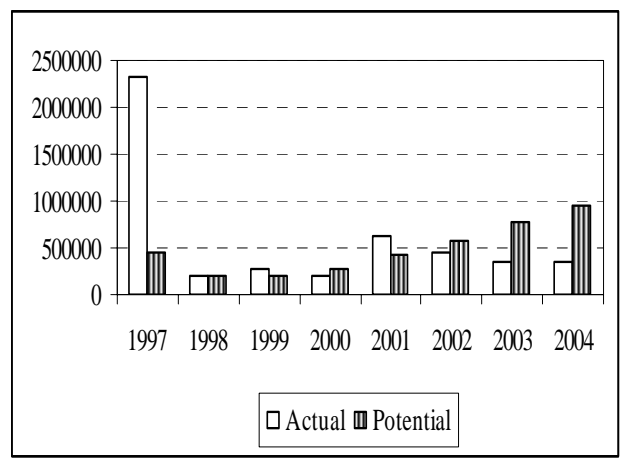

\section{Conclusion}

Using a gravity model approach, this study analysed the determinants of South African exports of leather products using annual data for the period 1997 to 2004. It then investigated if there is unexploited trade potential in the leather sector. The model was estimated for 32 trading partners in leather products. The analysis revealed that importers’ GDP, South Africa’s GDP, importer's population, infrastructure for both the importer and South Africa have a positive impact on the export of leather products. As South African population increases, the export of leather products decreases and this may suggests that the domestic market is expanding and few leather products are exported. Although an appreciation of the real exchange rate discourages exports, it is statistically insignificant. Transport costs as proxied by distance is associated with a decrease in the export of leather products.

Regional trade agreements are associated with trade diversion from South Africa export of leather products. Membership of the EU, NAFTA and ASIA is associated with a 
decrease in the export of leather products. It also export less products to countries where English is the official language. This suggests that trade agreements cause trade to be diverted away from South Africa’s leather products.

The estimated fixed effects model was simulated to determine if there is unexploited trade potential. The determination of export potential is of importance especially in uncertain markets. The investigation shows that South Korea, United Kingdom, USA, Zambia and Zimbabwe have unexploited export potential at least from 2002 to 2004. These results are important for trade analysts and policymakers to ensure that South Africa exports leather products to its potential level in order accelerate growth and alleviate poverty.

\section{REFERENCES}

Abou-Stait, F. (2005) Are Exports the Engine of Economic Growth? An Application of Cointegration and Causality Analysis for Egypt, 1977-2003. Economic Research Working Paper Series, Tunis: African Development Bank.

Anderson, J.E. (1979) “A theoretical Foundation for the Gravity Equation”, American Economic Review, 69(1): 106-116.

Bergstrand, J.H. (1985) "The Gravity Equation in International Trade: Some Microeconomic Foundations and Empirical Evidence", Review of Economics and Statistics, 67(3): 474-480. 
Bergstrand, J.H. (1989) “The Generalised Gravity Equation, Monopolistic Competition and the Factor-Proportions Theory in International Trade”, Review of Economics and Statistics, 71(1): 143-153.

Bougheas, S., Demetriades, P.O. and Mongernroth, E.L.W. (1999): "Infrastructure, Transport Costs and Trade”, Journal of International Economics, 47:469-189.

Breusch, F. and Egger, (1999) "How Reliable are Estimations of East-West Trade Potentials Based on Cross-section Gravity Analyses”, Empirica, 26(2): 81-99

Carrère, C. (2006) "Revisiting the Effects of Regional Trade Agreements on Trade Flows with Proper Specification of the Gravity Model”, European Economic Review, 50: 223247.

Egger, P. (2000) “A Note on the Proper Econometric Specification of the Gravity Equation”, Economic Letters, 66: 25-31.

Hadri, K. (2000) “Testing for Stationarity in Heterogeneous Panel Data”, Econometric Journal, 3(2): 148-161.

Im, K.S., Pesaran, M.H. and Shin, Y. (2003) "Testing for Unit Roots in Heterogeneous Panels”, Journal of Econometrics, 115: 53-74.

Jakab, Z.M. Kovacs, M.A. and Oszlay, A. (2001) "How Far has Regional Integration Advanced?: An Analysis of the Actual and Potential Trade of Three Central and European Countries”, Journal of Comparative Economics, 29: 276-292. 
Levin, A., Lin, C.F. and Chu, C. (2002): "Unit Roots Tests in Panel Data: Asymptotic and Finite Sample Properties”, Journal of Econometrics, 108: 1-24.

Longo, R. and Sekkat, K. (2004): “Economic Obstacles to Expanding Intra-African Trade”, World Development, 32(8): 1309-1321.

Martinez-Zarzoso, I. and Nowak-Lehmann, F. (2003) “Augmented Gravity Model: An Empirical Application to Mercosur-European Union Trade Flows”, Journal of Applied Economics, 6(2): 291-316.

Mátyás, L. (1997): “Proper Econometric Specification of the Gravity Model”, World Economy, 20(3): 363-368.

Naude, W.A., Oostendorp, R. and Serumaga-Zake, P. (2005) "Determinants of Manufacturing Exports: Results from a Regional Firm-Level Survey in South Africa”, Journal of Studies in Economics and Econometrics, 29(2): 108-116.

Nilsson, L. (2000) “Trade Integration and the EU Economic Membership Criteria”, European Journal of Political Economy, 16: 807-827.

Oguledo, V.I. and Macphee, C.R. (1994) “Gravity Models: A Reformulation and an Application to Discriminatory Trade Arrangements”, Applied Economics, 26: 107-120

Pöyhönen, P. (1963) “A Tentative Model for the Volume of Trade Between Countries”, Weltwirtschaftliches Archiv, 90: 93-99.

Presidency Republic of South Africa (2006): Accelerated and Shared Growth Initiative South Africa (ASGISA). Pretoria: Presidency Republic of South Africa. 
Sapir, A. (1981) "Trade Benefits Under EEC Generalised System of Preferences", European Economic Review, 15 (3): 339-355.

Silva, J.M.C and Tenreyro, S. (2006) “The Log of Gravity”, Review of Economics and Statistics, 88(4): 641-658.

Strauss, J. and Yigit, T. (2003) "Shortfalls of Panel Unit Root Testing", Economic Letters, 81: 309-313.

Tinbergen, J. (1962) Shaping the World Economy. Suggestion for an International Economic Policy, New York.

Tri Do, T. (2006) A Gravity Model for Trade Between Vietnam and Twenty-Three European Countries, Unpublished Doctorate Thesis, Department of Economics and Society,

Tsen, W.H. (2006) “Granger Causality Tests Among Openness to International Trade, Human Capital Accumulation and Economic Growth in China: 1952-1999”, International Economic Journal, 20(3): 285-302. 


\section{Appendix}

Table A1. Countries used in the estimation and their specific effects

\begin{tabular}{|c|c|}
\hline AUSTRALIA & 1.500872 \\
\hline AUSTRIA & 5.908021 \\
\hline BELGIUM & 5.589258 \\
\hline BRAZIL & -11.1159 \\
\hline CANADA & -5.3174 \\
\hline CHINA & -20.8783 \\
\hline CZECHOSLOVAKIA & 4.917369 \\
\hline FRANCE & -3.41148 \\
\hline GERMANY & -5.78248 \\
\hline GREECE & 7.602915 \\
\hline HONG KONG & 12.43836 \\
\hline INDIA & -19.4671 \\
\hline INDONESIA & -11.0588 \\
\hline ITALY & -0.031 \\
\hline JAPAN & -7.37954 \\
\hline SOUTH KOREA & -0.21938 \\
\hline MEXICO & -5.1869 \\
\hline MOZAMBIQUE & 6.366113 \\
\hline NETHERLANDS & 1.987187 \\
\hline PAKISTAN & -8.69108 \\
\hline PORTUGAL & 5.634712 \\
\hline SINGAPORE & 14.59001 \\
\hline SPAIN & -1.24671 \\
\hline SWITZERLAND & 5.267339 \\
\hline THAILAND & -1.57223 \\
\hline
\end{tabular}




$\begin{array}{lc}\text { TURKEY } & -0.76604 \\ \text { UNITED ARAB EMIRATES } & 12.83118 \\ \text { UNITED KINGDOM } & -4.8977 \\ \text { UNITED STATES OF AMERICA } & -14.2233 \\ \text { URUGUAY } & 16.4026 \\ \text { ZAMBIA } & 10.06027 \\ \text { ZIMBABWE } & 10.14918\end{array}$

\section{Data description and sources}

The study covers the period 1997 to 2004 and uses annual data. Thirty two main trading partners in raw hides and skins (other than fur skins) and leather (H41) were included in the estimation. The data for exports were obtained from the website of Trade and Industrial Policy Strategies (TIPS): http://www.tips.org.za. The data for populations were sourced from the World Bank’s World Development Indicators. The data for GDP were obtained from the IMF's International Financial Statistics Yearbook. Distance is a proxy for transport costs and was computed as distance in kilometers between Pretoria and trading partners' capital cities. They were taken from http://www.timeanddate.com. Infrastructure for both South Africa and the importing countries were proxied by the number of aircraft departures and were taken from the World Bank’s World Development Indicators. Although it may not be an appropriate proxy for infrastructure, it is the only variable with complete data. The data for other variables such as roads, railways are not available or are incomplete. The English language dummy variable was sourced from Silva and Tenreyro (2006). 
